\title{
Biotechnological Potential of Rhodococcus Biodegradative Pathways
}

\author{
Dockyu Kim ${ }^{1 *}$, Ki Young Choi ${ }^{2}$, Miyoun Yoo ${ }^{3}$, Gerben J. Zylstra ${ }^{4}$, and Eungbin Kim ${ }^{5}$ \\ ${ }^{1}$ Division of Polar Life Sciences, Korea Polar Research Institute, Incheon 21990, Republic of Korea \\ ${ }^{2}$ University College, Yonsei University, Incheon 21983, Republic of Korea \\ ${ }^{3}$ Korea Research Institute of Chemical Technology, Daejeon 34114, Republic of Korea \\ ${ }^{4}$ Department of Biochemistry and Microbiology, School of Environmental and Biological Sciences, Rutgers University, NJ 08901-8520, USA \\ ${ }^{5}$ Department of Systems Biology, Yonsei University, Seoul 03722, Republic of Korea
}

Received: December 8, 2017
Revised: March 26, 2018
Accepted: May 1, 2018
First published online
May 8, 2018
*Corresponding author
Phone: +82-32-760-5525;
Fax: +82-32-760-5509;
E-mail: envimic@kopri.re.kr
pISSN 1017-7825, eISSN 1738-8872
Copyright@ 2018 by
The Korean Society for Microbiology
and Biotechnology

\section{Introduction}

The genus Rhodococcus is a phylogenetically and physiologically diverse bacterial group within nocardioform actinomycetes, which contain mycolic acid in their cell walls. Rhodococcus (family Nocardiaceae) belongs to the phylum Actinobacteria that includes two other well-known families, Mycobacteriaceae and Corynebacteriaceae. Rhodococcus members are described as nonmotile and aerobic gram-positive bacteria that generally show pleomorphic morphology, depending on the species or growth conditions, such as different growth substrates. They have been isolated from a wide variety of sources, including soil, rocks, groundwater, marine sediments, animal feces, internal organs of insects, and healthy and diseased animals and plants [1]. Recently, cold-adapted rhodococcal strains have been isolated from naturally cold environments, such as alpine areas, the Arctic, and the Antarctic [2-4].

After approximately a decade since the first comprehensive account of the genus Rhodococcus in 1998 (see the special issue of Antonie Van Leeuwenhoek, volume 74), an excellent book was published that described the biology of Rhodococcus.
According to this book, rhodococci are generally found to be harmless, and some are very attractive biotechnological candidates, although there are rare pathogenic species such as $R$. equi and R. fascians that cause foal pneumonia and leafy gall disease in plants, respectively. The reasons for their value as promising biotechnological candidates for applications are as follows. The members of Rhodococcus show a remarkable ability to degrade and transform a wide variety of natural organic and xenobiotic compounds via diverse catabolic pathways. In addition to the capacity to metabolize a broad spectrum of chemical compounds, cell tolerance to toxic substrates and solvents, a frequent lack of catabolite repression, the production of biosurfactants, and environmental persistence make them excellent candidates for bioremediation and bioconversion. They also have the potential to synthesize useful products such as valuable chemical synthons, amides, and polymers [1,5].

The metabolic versatility of Rhodococcus has been extensively studied in microbial biotechnology fields worldwide. Presently, there are over 1,800 and over 3,200 patents retrieved by even a quick search on Google's patent search engine using "rhodococcus biodegradation" and 
"rhodococcus biocatalysis," respectively, as keywords. Several review papers have also described the biotechnological potential of rhodococci cells and their biodegradative enzymes for pollutant removal in environmental biotechnology and for biocatalysis in pharmaceutical and chemical industries [6, 7]. The biodegradation and biocatalysis activities are linked by biotransformation reactions and enzymes that catalyze the reactions. In this review, we will briefly summarize the current knowledge on the biodegradative pathways of Rhodococcus, including a brief collation of selected genomic data. We will then describe examples and strategies for utilizing the real and potential value of biodegradative rhodococci.

\section{Rhodococci as Superb Degraders}

As summarized in Table 1, rhodococci display a diverse range of metabolic capabilities and degrade a wide variety of natural organic and xenobiotic compounds, including aliphatic, aromatic (halogenated and nitro-substituted), heterocyclic, and polycyclic aromatic compounds [1], alicyclic hydrocarbons [8], nitriles [5], cholesterol [9], and lignins [10]. The wide range of substrates metabolized by rhodococci suggests that members of this genus are comparable to pseudomonads in their biotechnological applications. The biodegradative pathways in rhodococci generally consist of many peripheral (upper) pathways and a few central (lower) pathways. For example, in the case of aromatic hydrocarbons, a wide range of monooxygenases and dioxygenases in the peripheral pathways initiate the oxidative attack of the aromatic ring, producing central intermediates such as catechol, protocatechuate, and gentisate, which are further degraded by the ortho-, meta-, or modified 3-oxoadipate routes to intermediates of the

Table 1. Members of the genus Rhodococcus that possess biocatalytic enzymes and/or biodegradative pathways for representative organic compounds.

\begin{tabular}{|c|c|c|c|c|c|}
\hline Strain name & $\begin{array}{l}\text { Isolation } \\
\text { source }\end{array}$ & $\begin{array}{l}\text { Degradation } \\
\text { substrate }\end{array}$ & $\begin{array}{l}\text { Application } \\
\text { field }\end{array}$ & Key pathway or enzyme & $\begin{array}{l}\text { Reference } \\
\text { for } \\
\text { isolation }\end{array}$ \\
\hline $\begin{array}{l}\text { R. rhodochrous } \\
\mathrm{J} 1\end{array}$ & Soil sample & Benzonitrile & $\begin{array}{l}\text { Production of } \\
\text { acrylamide }\end{array}$ & $\begin{array}{l}\text { Nitrile hydratase } \\
\text { (H_NHase } \alpha \text { and } \beta \text { subunits) }\end{array}$ & {$[72]$} \\
\hline R. opacus $1 \mathrm{CP}$ & $\begin{array}{l}\text { Contaminated soil } \\
\text { in Moscow, Russia }\end{array}$ & $\begin{array}{l}\text { 4-Chlorophenol, } \\
\text { 2,4-dichlorophenol }\end{array}$ & $\begin{array}{l}\text { Remediation of } \\
\text { (chloro)aromatics }\end{array}$ & $\begin{array}{l}\text { Modified ortho-cleavage } \\
\text { pathway for chlorocatechols }\end{array}$ & [73] \\
\hline $\begin{array}{l}\text { R. rhodochrous } \\
\text { PA-34 }\end{array}$ & Soil sample & Propionitrile & $\begin{array}{l}\text { Production of } \\
\text { acrylamide }\end{array}$ & $\begin{array}{l}\text { Nitrile hydratase } \\
\text { (H_NHase } \alpha \text { and } \beta \text { subunits) }\end{array}$ & {$[74]$} \\
\hline $\begin{array}{l}\text { R. erythropolis } \\
\text { TA421 }\end{array}$ & $\begin{array}{l}\text { Dry wood termites, } \\
\text { Japan }\end{array}$ & Biphenyl & $\begin{array}{l}\text { Remediation of } \\
\text { organic pollutants }\end{array}$ & $\begin{array}{l}\text { Biphenyl-degrading genes } \\
(b p h)\end{array}$ & {$[75]$} \\
\hline $\begin{array}{l}\text { R. erythropolis } \\
\text { BD2 }\end{array}$ & $\begin{array}{l}\text { Trichloroethene- and } \\
\text { toluene-contaminated soil }\end{array}$ & Isopropylbenzene & $\begin{array}{l}\text { Remediation of } \\
\text { trichloroethene }\end{array}$ & $\begin{array}{l}\text { Isopropylbenzene- } \\
\text { degrading genes (ipb) }\end{array}$ & {$[12]$} \\
\hline $\begin{array}{l}\text { Rhodococcus sp. } \\
\text { AJ270 }\end{array}$ & $\begin{array}{l}\text { Air-dried soil from an } \\
\text { industrial site, UK }\end{array}$ & $\begin{array}{l}\text { Acetonitrile, } \\
\text { heteroaromatic } \\
\text { nitriles }\end{array}$ & $\begin{array}{l}\text { Remediation of } \\
\text { acrylonitrile }\end{array}$ & $\begin{array}{l}\text { Nitrile hydratase and } \\
\text { amidase }\end{array}$ & {$[76]$} \\
\hline R. jostii RHA1 & $\begin{array}{l}\text { Hexachlorocyclohexane- } \\
\text { contaminated soil, } \\
\text { Japan }\end{array}$ & $\begin{array}{l}\text { Polychlorinated } \\
\text { biphenyl, } \\
\text { alkylbenzenes }\end{array}$ & $\begin{array}{l}\text { Remediation of } \\
\text { organic pollutants; } \\
\text { vanillin production }\end{array}$ & $\begin{array}{l}\text { Biphenyl- and ethylbenzene- } \\
\text { degrading genes (bph and } e t b) \text {; } \\
\text { dye-decolorizing peroxidase } \\
(d y p B)\end{array}$ & {$[77]$} \\
\hline $\begin{array}{l}\text { Rhodococcus sp. } \\
\text { T104 }\end{array}$ & Plant-amended soil & $\begin{array}{l}\text { Biphenyl, } \\
\text { terpenes }\end{array}$ & $\begin{array}{l}\text { Remediation of } \\
\text { polychlorinated } \\
\text { biphenyls }\end{array}$ & $\begin{array}{l}\text { Biphenyl-degrading genes } \\
(b p h)\end{array}$ & {$[78]$} \\
\hline $\begin{array}{l}\text { Rhodococcus sp. } \\
\text { B-264-1 }\end{array}$ & $\begin{array}{l}\text { Oil-contaminated soil, } \\
\text { USA }\end{array}$ & Toluene & $\begin{array}{l}\text { Production of } \\
\text { cis-(1S,2R)-indandiol }\end{array}$ & $\begin{array}{l}\text { Toluene dioxygenase } \\
(\text { todC1C2BA) }\end{array}$ & {$[79]$} \\
\hline $\begin{array}{l}\text { Rhodococcus sp. } \\
\text { strain }\end{array}$ & $\begin{array}{l}\text { Terra Nova Bay, } \\
\text { Antarctica }\end{array}$ & $\begin{array}{l}\text { n-Alkanes, } \\
\text { biphenyl }\end{array}$ & $\begin{array}{l}\text { Low-temperature } \\
\text { remediation }\end{array}$ & $\begin{array}{l}n \text {-Alkane-degrading and } \\
\text { biosurfactant-producing genes }\end{array}$ & [80] \\
\hline $\begin{array}{l}\text { R. opacus } \\
\text { PWD4 }\end{array}$ & $\begin{array}{l}\text { Topsoil in Hilversum, } \\
\text { The Netherlands }\end{array}$ & Toluene & $\begin{array}{l}\text { Production of } \\
\text { trans-carveol }\end{array}$ & Limonene-6-hydroxylase & {$[53]$} \\
\hline
\end{tabular}


Table 1. Continued.

\begin{tabular}{|c|c|c|c|c|c|}
\hline Strain name & $\begin{array}{l}\text { Isolation } \\
\text { source }\end{array}$ & $\begin{array}{l}\text { Degradation } \\
\text { substrate }\end{array}$ & $\begin{array}{l}\text { Application } \\
\text { field }\end{array}$ & Key pathway or enzyme & $\begin{array}{l}\text { Reference } \\
\text { for } \\
\text { isolation }\end{array}$ \\
\hline $\begin{array}{l}\text { Rhodococcus } \\
\text { sp. DK17 }\end{array}$ & $\begin{array}{l}\text { Crude oil-contaminated } \\
\text { soil, Korea }\end{array}$ & $\begin{array}{l}\text { Alkylbenzenes, } \\
\text { phthalates, } \\
\text { bicyclics }\end{array}$ & $\begin{array}{l}\text { Production of } \\
\text { cis-dihydrodiols and } \\
\text { catechols }\end{array}$ & $\begin{array}{l}o \text {-Xylene dioxygenase } \\
(a k b A 1 A 2 A 3) \text { and } c i s-\text { dihydrodiol } \\
\text { dehydrogenase }(a k b B)\end{array}$ & [81] \\
\hline $\begin{array}{l}\text { Rhodococcus } \\
\text { sp. NO14-1 }\end{array}$ & $\begin{array}{l}\text { Petroleum hydrocarbon- } \\
\text { contaminated alpine soil, } \\
\text { Austria }\end{array}$ & $\begin{array}{l}\text { Hexadecane, } \\
\text { phenol }\end{array}$ & $\begin{array}{l}\text { Low-temperature } \\
\text { remediation of } \\
\text { phenol }\end{array}$ & Phenol-degrading genes & [82] \\
\hline R. opacus B4 & Soil in Hiroshima, Japan & $\begin{array}{l}\text { Benzene, } \\
\text { aromatic/aliphatic }\end{array}$ & $\begin{array}{l}\text { Remediation of } \\
\text { benzene }\end{array}$ & Benzene dioxygenase (bnzA1A2) & [83] \\
\hline $\begin{array}{l}\text { R. erythropolis } \\
\text { PR4 }\end{array}$ & $\begin{array}{l}\text { Deep sea of the Pacific } \\
\text { Ocean }\end{array}$ & Alkanes & $\begin{array}{l}\text { Remediation of } \\
\text { alkanes }\end{array}$ & Alkane-degrading genes (alk) & [84] \\
\hline $\begin{array}{l}\text { R. erythropolis } \\
\text { MLT1 }\end{array}$ & $\begin{array}{l}\text { Soil surrounding hop } \\
\text { plants }\end{array}$ & $\beta$-Myrcene & $\begin{array}{l}\text { Production of } \\
\text { geraniol }\end{array}$ & Unknown enzymatic mechanism & [54] \\
\hline R. ruber $\mathrm{TH}$ & Nitrile-contaminated soil & Acrylonitrile & $\begin{array}{l}\text { Production of } \\
\text { ammonium acrylate }\end{array}$ & Nitrilase & [85] \\
\hline $\begin{array}{l}\text { R. ruber } \\
\text { AKSH-84 }\end{array}$ & $\begin{array}{l}\text { Petroleum-contaminated } \\
\text { sludge, India }\end{array}$ & Acetonitrile & $\begin{array}{l}\text { Production of acrylic } \\
\text { acid }\end{array}$ & Nitrilase & [42] \\
\hline $\begin{array}{l}\text { Rhodococcus } \\
\text { spp. strains }\end{array}$ & $\begin{array}{l}\text { Petroleum hydrocarbon- } \\
\text { contaminated North } \\
\text { Atlantic Canada }\end{array}$ & $\begin{array}{l}n \text {-Hexadecane, } \\
\text { diesel }\end{array}$ & $\begin{array}{l}\text { Low-temperature } \\
\text { remediation }\end{array}$ & $\begin{array}{l}n \text {-Alkane-degrading and } \\
\text { biosurfactant-producing genes }\end{array}$ & [86] \\
\hline $\begin{array}{l}\text { R. erythropolis } \\
\text { ATCC } 25544\end{array}$ & Soil & $\begin{array}{l}\text { Cholesterol, } \\
\text { aromatic } \\
\text { compounds }\end{array}$ & $\begin{array}{l}\text { Production of } \\
\text { cholestenone }\end{array}$ & Cholesterol oxidase & Unknown \\
\hline
\end{tabular}

citric acid cycle.

Biodegradative rhodococci often harbor large catabolic linear plasmids, many of which increase their catabolic versatility and efficiency by contributing to multiple pathways and gene homologs. Such plasmids encode multiple catabolic enzyme systems. Thus, multiple degradative pathways may be involved in the degradation of various organic compounds. Comparative analyses of rhodococcal genomes have suggested that the linear plasmids are possible determinants of the propagation of diverse degradative genes [11]. It is thought that frequent recombination of catabolic genes among bacteria is associated with large plasmids. The hyper recombination contributes to the large number of homologous genes in large genomes, which consequently leads to their catabolic diversity [1]. As representative examples, the highly similar gene clusters for catabolism of aromatic compounds are found on the following three pairs of plasmids: pTA421 from $R$. erythropolis TA421 and pSP6 from R. globerulus P6, pBD2 from $R$. erythropolis BD2 [12] and pRHL1 from R. jostii RHA1, and pDK2 from Rhodococcus sp. DK17 and pRHL2 from $R$. jostii RHA1. In addition to enzyme and pathway multiplicities, different induction mechanisms, substrate specificities, and activities of the catalytic enzymes are thought to contribute to their extraordinary capabilities to metabolize a wide range of compounds.

Since the introduction of the term "megaplasmid" in 1981 to describe a more than $450 \mathrm{~kb}$ plasmid from Rhizobium meliloti, there have been many reports on the presence of megaplasmids in different bacteria, which encode the degradation enzymes for various classes of natural and synthetic organic compounds. Table 2 summarizes the brief genome comparisons of biodegradative rhodococci containing catabolic plasmids. These genomes vary in size (5.4-10.1 Mbp) and the number of predicted genes (5,023$9,251)$. Among the biodegradative rhodococci, $R$. jostii RHA1 is the most extensively studied strain. RHA1 is a versatile polychlorinated biphenyl degrader, which contains a linear chromosome and three linear megaplasmids $(1,120-\mathrm{kb}$ pRHL1, 420-kb pRHL2, and 330-kb pRHL3). Most of the genes of the upper biphenyl catabolic pathway are located mainly on the pRHL1 and pRHL2 plasmids, whereas duplicated phthalate-degrading operons are located on pRHL1 and pRHL2 [13]. Oxygenases genes (203) are 
Table 2. Brief genome statistics of Rhodococcus strains possessing catabolic plasmids. ${ }^{a}$

\begin{tabular}{|c|c|c|c|c|c|c|}
\hline Strain name & $\begin{array}{c}\text { Isolation source } \\
\text { (degrading substances) }\end{array}$ & $\begin{array}{c}\text { Genome } \\
\text { size, } \mathrm{Mb} \\
(\mathrm{GC} \%)\end{array}$ & $\begin{array}{l}\text { Total } \\
\text { gene } \\
\text { count }\end{array}$ & $\begin{array}{l}\text { Total } \\
\text { protein } \\
\text { count }\end{array}$ & $\begin{array}{l}\text { Number } \\
\text { of } \\
\text { plasmids }\end{array}$ & $\begin{array}{c}\text { NCBI } \\
\text { BioProject } \\
\text { ID }\end{array}$ \\
\hline R. jostii RHA1 & $\begin{array}{l}\text { Hexachlorocyclohexane-contaminated soil } \\
\text { (polychlorinated biphenyl, alkylbenzenes) }\end{array}$ & $9.71(66.94)$ & 9,251 & 8,695 & 3 & PRJNA13693 \\
\hline R. erythropolis PR4 & Deep sea (alkanes) & $6.90(62.29)$ & 6,428 & 6,278 & 3 & PRJDA20395 \\
\hline R. opacus B4 & Soil (aromatic and aliphatic hydrocarbons) & $8.83(67.63)$ & 8,048 & 7,780 & 5 & PRJDA34839 \\
\hline Rhodococcus sp. DK17 & $\begin{array}{l}\text { Crude oil-contaminated soil } \\
\text { (alkylbenzenes, bicyclics, phthalates) }\end{array}$ & $9.11(67.10)$ & 8,609 & 7,954 & 3 & PRJNA157361 \\
\hline R. aetherivorans BCP1 & Aerobic butane-utilizing consortium (alkanes) & $6.23(70.29)$ & 5,644 & 5,478 & 2 & PRJNA213668 \\
\hline R. pyridinivorans SB3094 & Diesel waste site (butanone) & $5.59(67.81)$ & 5,094 & 4,916 & 2 & PRJNA231235 \\
\hline R. opacus R7 & $\begin{array}{l}\text { Polycyclic aromatic hydrocarbon-contaminated } \\
\text { site (naphthalene, } o \text {-xylene) }\end{array}$ & $10.12(67.02)$ & 8,621 & 8,357 & 5 & PRJNA246296 \\
\hline R. opacus $1 \mathrm{CP}$ & Contaminated soil (chloroaromatics) & $8.64(67.03)$ & 7,608 & 7,420 & 2 & PRJNA253567 \\
\hline Rhodococcus sp. p52 & Oil-polluted soil (dioxin) & $5.41(67.85)$ & 5,023 & 4,801 & 3 & PRJNA255270 \\
\hline Rhodococcus sp. AD45 & Freshwater sediment (isoprene) & $6.79(61.74)$ & 6,202 & 6,048 & 2 & PRJNA272922 \\
\hline
\end{tabular}

a Based on the National Center for Biotechnology Information (NCBI) genome information accessed in mid-May 2017.

exceptionally rich in the RHA1 genome, containing 9,251 predicted protein-encoding genes, many of which are involved in numerous pathways predicted to degrade aromatic compounds (30) or steroids (4) [14]. Another well-studied Rhodococcus strain, DK17, utilizes various alkylbenzenes and phthalates as growth substrates, and also possesses three linear megaplasmids (380-kb pDK1, 330-kb pDK2, and 750-kb pDK3). The genes for alkylbenzene degradation are present in $\mathrm{pDK} 2$, whereas the gene clusters for phthalate degradation are duplicated in both $\mathrm{pDK} 2$ and pDK3. Duplicated phthalate-degrading operons are equally functional, allowing DK17 to achieve the maximal degradation of phthalate [15]. In addition, it is noteworthy that the phthalate degradation pathway is completely inhibited by benzoate in DK17 [16].

The genomic features of $R$. jostii RHA1 and Rhodococcus sp. DK17 were compared to study basic genetic similarities and differences between the two strains. A comparative protein-protein BLAST analysis (BLASTp) showed that approximately $75 \%$ of open-reading frames (ORFs) from the two strains, including ones for the degradation of aromatics, share $>90 \%$ identity. Almost identical phthalate operons duplicated on two separate catabolic megaplasmids were also present in the RHA1 genome as in DK17. The DK17-specific ORFs are not randomly distributed over the genome, but occur in groups or clusters. Analyses of the DK17-specific ORFs indicated that many encoded proteins are likely to be involved in the transport of organic molecules, such as aromatic hydrocarbons [17]. This is consistent with the recent genomic discovery that biodegradative rhodococci are well-equipped with genes for the transport of many different substrates [18].

\section{Metabolic Pathways for o-Xylene Degradation as a Representative Example}

Most 0 -xylenes are produced by cracking petroleum and largely used in the production of phthalic anhydride, which is a precursor to many materials, drugs, and other chemicals. Thus, it is a widespread environmental pollutant in groundwater and soil. Although bacteria capable of degrading $m$-xylene or $p$-xylene under aerobic conditions are common, bacteria capable of degrading 0 -xylene are less frequently reported. Thus, $o$-xylene is considered to be difficult to biologically degrade and only a few bacteria have been studied for the ability to degrade $o$-xylene. Five different possible metabolic pathways for 0 -xylene degradation were proposed (Fig. 1), three of which have been experimentally confirmed from Rhodococcus spp. until recently. Rhodococcus sp. DK17 and Rhodococcus sp. C125 (originally Corynebacterium sp. C125) metabolize 0 -xylene through an aromatic ring dioxygenation to form 0 -xylene cis-3,4-dihydrodiol (1,2-dihydoxy-3,4-dimethylcyclohexa3,5-diene), which is converted to 3,4-dimethylcatechol by a dehydrogenation reaction. Rhodococcus sp. B3 and R. opacus R7 degrade $o$-xylene through two successive monooxygenation reactions of the aromatic ring to form 2,3-dimethylphenol and 3,4-dimethylcatechol. In Rhodococcus sp. B3, a methyl 


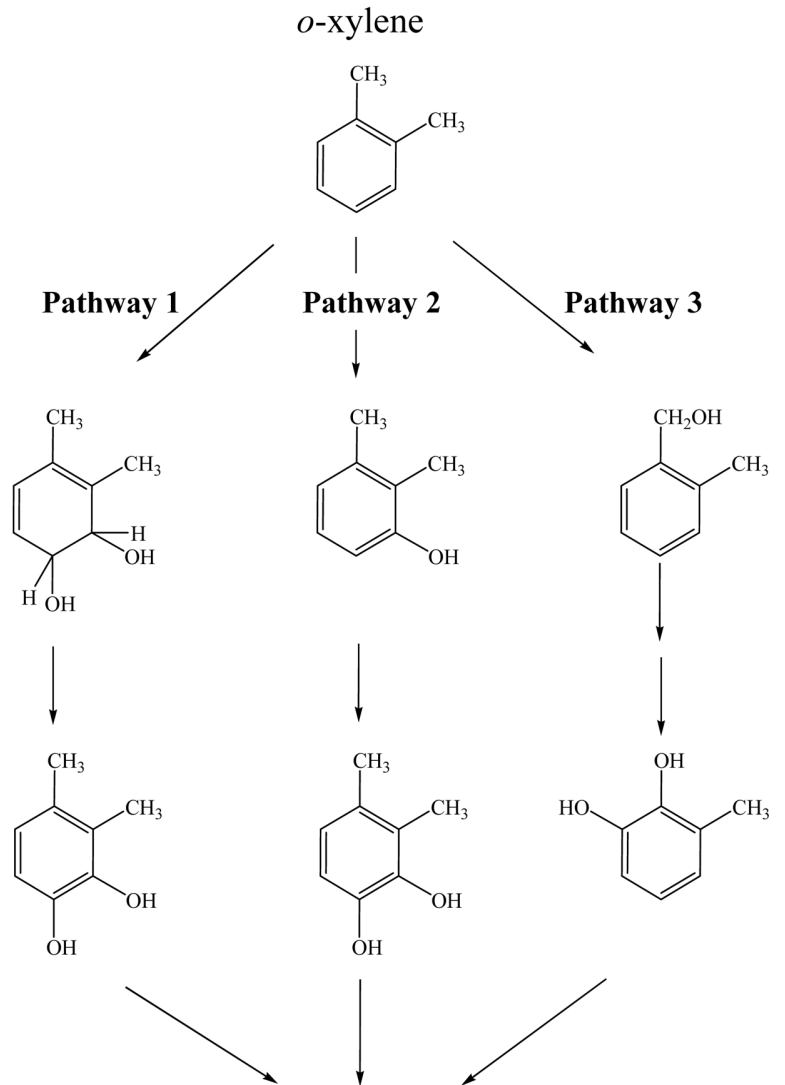

Pathway 1 (ring-dioxygenation):

Rhodococcus sp. C125

Rhodococcus sp. DK17

Pathway 2 (ring-monooxygenation):

Rhodococcus sp. B3

R. opacus $\mathrm{R} 7$

Pathway 3 (methyl-monooxygenation):

Rhodococcus sp. B3

R. opacus TKN14

Aromatic ring cleavage

Fig. 1. o-Xylene degradation pathways operating in Rhodococcus spp. isolates.

monooxygenation reaction operates simultaneously that oxidizes a methyl group of $o$-xylene to form 2-methylbenzyl alcohol, which is metabolized to form 3-methylcatechol via 2-methylbenzoic acid. The methyl monooxygenation pathway functions for $o$-xylene degradation in $R$. opacus TKN14, from which the genes (nidABEF) for methyl group hydroxylation have been identified and characterized [19]. The central intermediates (dimethyl or monomethyl catechols) are further degraded by ortho- or meta-ring cleavage to intermediates of the citric acid cycle.

An approximately 25-kb-size gene cluster for 0 -xylene degradation by Rhodococcus sp. DK17 is present on the 330-kb pDK2 (Fig. 2). The cluster contains the genes encoding $o$-xylene dioxygenase: large and small subunits of the oxygenase component, which are present in two copies $6 \mathrm{~kb}$ apart from each other $\left(a k b A 1_{a^{-}} a k b A 2_{a}\right.$ and $a k b A 1_{b^{-}}$ $\left.a k b A 2_{b}\right)$, a gene for the ferredoxin component ( $\left.a k b A 3\right)$, and a gene for the ferredoxin reductase component (akbA4). When expressed in Escherichia coli, recombinant AkbA1 $\mathrm{AkbA2}$ - $\mathrm{AkbA} 3$ transformed $o$-xylene into $o$-xylene cis-3,4- dihydrodiol. Moreover, a gene encoding cis-dihydrodiol dehydrogenase $(a k b B)$ and $a k b C D E F$ genes for a complete meta-cleavage pathway (meta-cleavage dioxygenase (AkbC), hydrolase $(\mathrm{AkbD})$, hydratase $(\mathrm{AkbE})$, and aldolase $(\mathrm{AkbF}))$ are present in the cluster. AkbBCDEF are thought to completely metabolize the intermediate cis-3,4-dihydrodiol produced by 0 -xylene dioxygenase [20]. Two-component regulatory genes ( $a k b S$ and $a k b T$ ) are detected near the $o$ xylene-degrading operon, which are required to induce the expression of $o$-xylene dioxygenase [21].

\section{Application of Targeted Biodegradative Pathways}

\section{Biodegradation}

Many alkyl- and hydroxyl-substituted aromatic hydrocarbons and nitriles are released into the environment by industrial activity, whereas some are natural products. Most aromatic hydrocarbons and nitriles are highly toxic, mutagenic, and carcinogenic. Microorganisms and their degradative pathways have been examined and used in an 
A

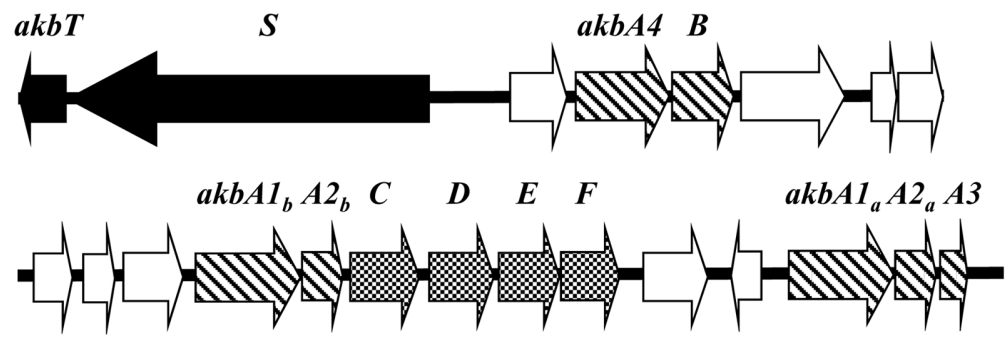

MIIII Upper pathway genes for $o$-xylene degradation

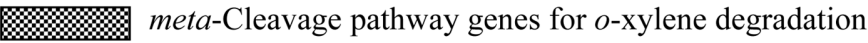

Two-component regulatory genes for $o$-xylene dioxygenase induction

B

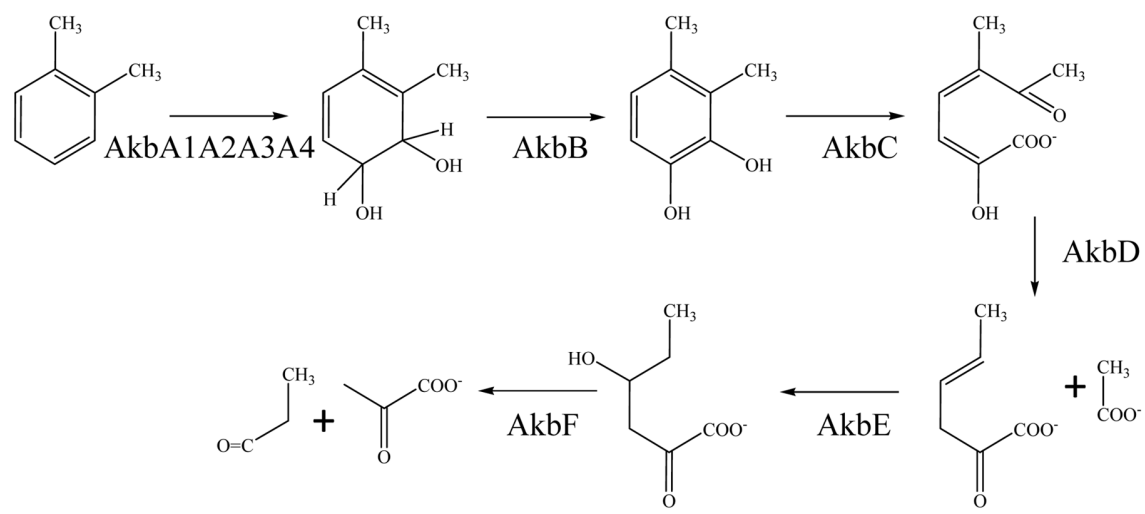

Fig. 2. Gene organization on the 330-kb pDK2 in Rhodococcus sp. DK17 (A), and proposed metabolic pathway for o-xylene degradation by DK17 (B).

The direction of transcription is indicated by arrowheads.

ecologically favorable process for the biodegradation of various pollutants at contaminated sites. The degradative capacities of aerobic rhodococci are of particular relevance for the bioremediation of organic pollutants derived from the constituents and halogenated products of petroleum. Indeed, there have been many studies involving the biological removal of aromatic and aliphatic hydrocarbons, such as benzene, chlorobenzene, phenol, o-xylene, naphthalene, and $n$-alkanes, using Rhodococcus strains that grew in extraordinarily high concentrations of pollutants and/or metabolized them at high degradative rates $[22,23]$.

As mentioned above, it has been examined if the rhodococcal strains with $o$-xylene degradation ability are able to remove $o$-xylene at a small scale in a laboratory and then be exploited for in situ $o$-xylene removal in natural environments where the strains were originally isolated. A laboratory-scale biofilter inoculated with $o$-xylene degrading Rhodococcus sp. BTO62 maintained more than 90\% removal efficiency of $o$-xylene $\left(41 \mathrm{~g} / \mathrm{m}^{3} / \mathrm{h}\right)$ under sterile condition and the efficiency was enhanced to $160 \mathrm{~g} / \mathrm{m}^{3} / \mathrm{h}$ under nonsterile condition. This indicates the possibility that $o$-xylene and its degradation intermediates are co-metabolized by BTO62 and other contaminant microorganisms in the biofilter [24]. When co-inoculated with $m$ - and $p$-xylenedegrading Pseudomonas sp. NBM21, BTO62 was able to remove a mixture of $o-, m-$, and $p$-xylenes at an elimination capacity of $180 \mathrm{~g} / \mathrm{m}^{3} / \mathrm{h}$ at $20^{\circ} \mathrm{C}$ under nonsterile conditions [25]. Rhodococcus sp. RHA1 possesses two well-known degradative gene clusters for biphenyl $(b p h)$ and $o$-xylene (homologous to DK17 $a k b$ ) degradation. RHA1 was used, together with the bacterium Burkholderia xenovorans LB400 carrying adequate operons for chlorinated benzoate and biphenyl degradation, for sediment microcosms contaminated with a mixture of structurally similar compounds of polychlorinated biphenyls [26]. Rhodococcal cells immobilized in agar or synthetic polymers were also used for the bioremediation of acrylonitrile and toxic amides. Bioaugmentation application of Rhodococcus sp. AJ270 pure culture resulted in the same level of acrylonitrile degradation in the sterilized topsoil as that achieved by whole 
indigenous bacterial flora in unsterilized control soil [27].

Plant essential oils are abundant, inexpensive, and usually considered nontoxic to humans. Components in these oils have been reported both to stimulate bacterial cell growth and induce catalytic enzymes in their degradative pathways, resulting in higher degradation rates for biphenyl, polychlorinated biphenyls, and trichloroethylene (TCE). For example, the component limonene in orange peels was able to induce the biphenyl degradation pathway in limonene-degrading Rhodococcus sp. T104 [28]. The induction ability of these essential oil components is probably due to the similarity between their chemical structures and the pollutants. Thus, these essential oils or plant materials may be used as a cost-effective bioremediation strategy to stimulate environmental pollutant degradation. When induced by cumin aldehyde and cumene (two components in cumin oil), toluene-degrading Rhodococcus sp. L4 was capable of cometabolic degradation of TCE, with the degradation efficiency being similar to toluene grown cells ( $57 \pm 5 \%$ of the initial TCE concentration of $80 \mu \mathrm{M}$ ) [29]. To overcome the need for the repeated addition of inducing substrates to maintain TCE degradation activity, Rhodococcus sp. L4 was immobilized on cumin seeds as plantimmobilizing materials containing cumin aldehyde and cumene. The immobilized organisms tolerated up to $68 \mu \mathrm{M}$ TCE and continuously degraded TCE, demonstrating that rhodococcal immobilization on plant materials rich in essential oils is a promising method for efficient TCE cometabolic degradation [30].

Even naturally cold environments such as alpine areas and Arctic and Antarctic regions are known to be contaminated with various aromatic and aliphatic compounds. Oil spillage is one of the main concerns, and the petroleum-derived contaminants are generally thought to be persistent in the environment owing to their toxic effects on indigenous microbes and the low temperatures, which limit the rates of microbial degradative processes. However, cold-adapted bacteria play a key role in in situ biodegradation in the cold environments, and their degradative activities and community composition shifts have been extensively studied [31]. Thus, the psychrotolerant and/or psychrophilic bacteria have been characterized as useful tools for low-temperature bioremediation of the environmental contaminants $[32,33]$. Rhodococcus members from hydrocarbon-contaminated sites are commonly recognized for their high ability in petroleum hydrocarbon degradation. Several studies have reported the use of indigenous rhodococci to degrade phenolic pollutants in cold environments. Cold-adapted R. erythropolis BZ4 from alpine soil was able to degrade high amounts of phenol $(0.7 \mathrm{~g} / \mathrm{l})$ at as low a temperature as $15^{\circ} \mathrm{C}$ [34]. Rhodococcus sp. AQ5-07 from Antarctic soil was capable of completely degrading $0.5 \mathrm{~g} / 1$ phenol within $120 \mathrm{~h}$ at $10^{\circ} \mathrm{C}$ at the laboratory scale [35].

\section{Biocatalysis}

The generation of high-value chemicals from abundant and low-value renewable organic materials using microbial and/or enzymatic biocatalysts is an area of great interest to microbiologists and organic chemists. Biocatalysts are usually more effective than the use of traditional chemical methods, because they metabolize under mild conditions, with high specificity and stereoselectivity, which are needed in the (agro)chemical and the pharmaceutical industries. As shown in a representative review for the biocatalytic application of rhodococcal enzymes, Rhodococcus erythropolis contains a large number of enzymes that are involved in many diverse reactions in bioconversion and degradation processes, such as oxidations, dehydrogenations, epoxidations, hydrolysis, hydroxylations, dehalogenations, and desulfurizations [36]. Several representative bioconversion reactions by catalytic enzymes from Rhodococcus spp. strains are depicted in Fig. 3 and described in detail in the subsections below.

Aromatic compounds. Oxygenases are defined as enzymes that catalyze the specific introduction of one (monooxygenase) or two (dioxygenase) oxygen atoms into the substrate. Aromatic dioxygenases have attracted interest for their potential application as biocatalysts for the regioselective and enantioselective synthesis of vicinal cisdihydrodiols and their dehydrogenation product catechols [37]. As a result of the demand for chiral intermediates, dehydrogenases have also been used for the production of chiral compounds, such as substituted catechols. For example, the naphthalene cis-dihydrodiol dehydrogenase enzyme has been used for the production of catechol-like metabolites in biotransformation studies.

The o-xylene dioxygenase from Rhodococcus sp. DK17 possesses the unique ability to perform specific regioselective hydroxylations, depending on the size and position of the substituent groups on the aromatic ring [38]. Molecular modeling studies predicted that the substrate-binding pocket of the DK17 o-xylene dioxygenase is large enough to accommodate bicyclics, and can be divided into three regions (distal, central, and proximal), where hydrophobic interactions in the distal position may be important in substrate binding. Subsequent site-directed mutagenesis studies combined with metabolite analyses confirmed these 


\section{Low-molecular weight compounds}

\section{High-molecular weight compounds}

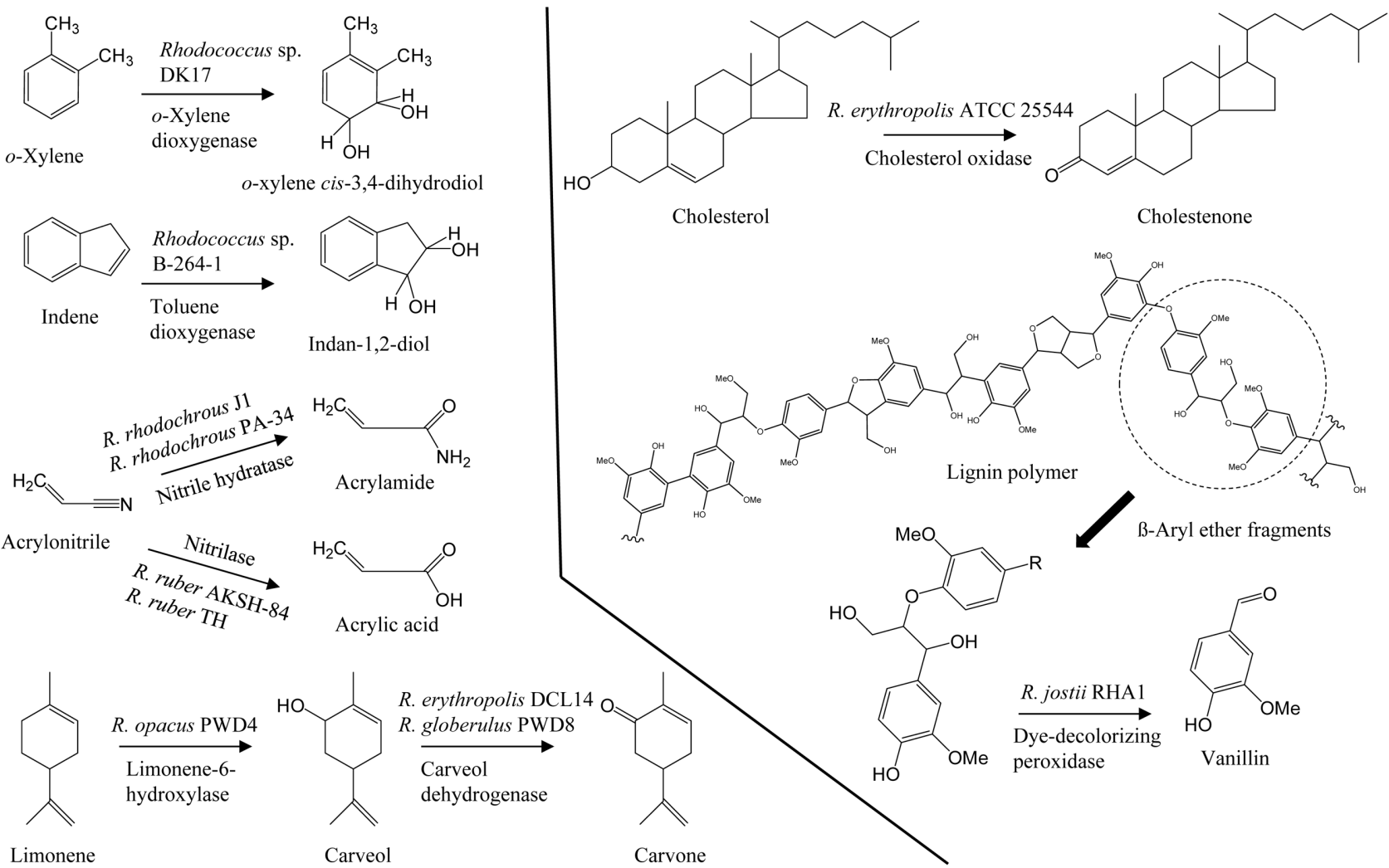

Fig. 3. Representative bioconversion reactions by catalytic enzymes from Rhodococcus spp. strains.

predictions, and further showed that different positioning of substrates in the active site of the enzyme resulted in the generation of different products. For example, DK17 transformed toluene and ethylbenzene into two different cis-dihydrodiols that resulted from an oxidation at the 2,3 and the 3,4 positions on the aromatic ring, whereas it transformed all of the larger substrates tested (biphenyl, naphthalene, indan, tetralin, indene, and 1,2dihydronaphthalene) exclusively into each corresponding cis-dihydrodiol [8]. Moreover, when expressed in Escherichia coli, the $o$-xylene dioxygenase (AkbA1A2A3) was able to transform tetralin, indene, and 1,2-dihydronaphthalene into each corresponding cis-dihydrodiol (tetralin cisdihydrodiol, indan-1,2-diol, and cis-1,2-dihydroxy-1,2,3,4tetrahydronaphthalene, respectively) [8]. These bioconversion studies suggested that the DK17 cells or recombinant 0 xylene dioxygenase, with the capability for aromatic and alicyclic hydroxylation of indan derivatives, could be used as a promising biocatalyst for the development of new chemicals (Fig. 4).
Indan and its derivatives are frequently used as starting materials for the preparation of synthons for pharmaceutical and fine chemical synthesis. Rhodococcus sp. I24, possessing a toluene dioxygenase, was capable of transforming indene to cis-(1S,2R)-indandiol, a potential precursor to (-)-cis$(1 S, 2 R)$-1-aminoindan-2-ol, a key chiral synthon for indinavir, an HIV protease inhibitor [39]. When scaled up in a 14-L bioreactor, Rhodococcus sp. B-264-1 produced 2,000 mg/1 of cis-(1S,2R)-indandiol (an enantiometric excess > 99\%) and yielded up to $4,000 \mathrm{mg} / 1$ in process development studies. In addition to the oxidation of indene to cis- $(1 S, 2 R)$ indandiol, indan and tetralin were transformed to a variety of indandiols for chiral drugs by enantioselective benzylic microbial hydroxylation [38]. Research has also been performed to obtain patentable melatonin receptor ligands, including synthesis of tricyclic indan derivatives for the development of new melatonin receptor agonists [40].

Nitriles. Nitriles are organic compounds that have a $-\mathrm{C} \equiv \mathrm{N}$ functional group. They are common environmental pollutants. Rhodococci have been shown to degrade and 
<smiles>Cc1ccccc1C</smiles><smiles>CC1=C(C(F)(F)F)C=CC[C@@H]1O</smiles><smiles>Cc1ccccc1</smiles>

3<smiles>CCc1ccccc1</smiles>

6<smiles>CC1Cc2ccccc2C1</smiles><smiles>O[C@H]1C=CC2=C(CCC2)[C@H]1O</smiles>

10<smiles>CC1CCc2ccccc2C1</smiles>

11<smiles>CC1=CC=C[C@H](O)[C@H]1O</smiles>

$$
4(80 \%)
$$<smiles>CC1=C[C@H](O)[C@H](O)C=C1</smiles>

$\mathbf{5}(20 \%)$<smiles>CCC1=CC=C[C@H](O)[C@]1(C)O</smiles><smiles>CCC1=C[C@H](O)[C@H](O)C=C1</smiles>
$\mathbf{8}(10 \%)$<smiles>Cc1cccc(C)c1</smiles>

13<smiles>CC1=CC(C)C(O)C=C1</smiles>

$\mathbf{1 5}(10 \%)$<smiles>CC[C@H]1C(C)=CC=C(C)[C@@H]1O</smiles>

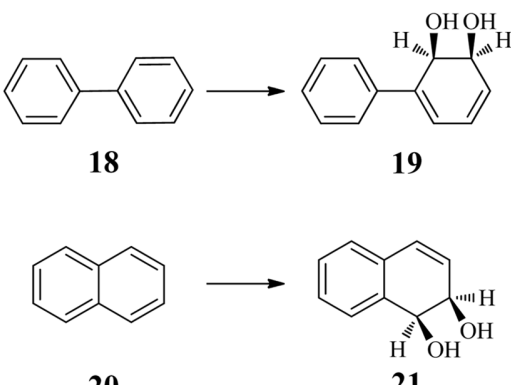

20

21<smiles>[Z17][C@@]1(O)c2ccccc2C[C@H]1OC</smiles>

22

23<smiles>O[C@H]1CCCc2ccccc21</smiles>

24

Fig. 4. Regioselective oxidation of monocyclics and bicyclics by Rhodococcus sp. DK17 o-xylene dioxygenase.

The oxidation product(s) from each substrate are as follows: 1, o-xylene; 2, 1,2-dihydroxy-3,4-dimethylcyclohexa-3,5-diene; 3, toluene; 4, cis-2,3toluene dihydrodiol; 5, cis-3,4-toluene dihydrodiol; 6, ethylbenzene; 7, cis-2,3-ethylbenzene dihydrodiol; 8, cis-3,4-ethylbenzene dihydrodiol; 9, indan; 10, cis-indan-4,5-dihydrodiol; 11, tetralin; 12, tetralin cis-dihydrodiol; 13, m-xylene; 14, 3-methylbenzyl alcohol; 15, 2,4-dimethylphenol; 16, p-xylene; 17, cis-p-xylene dihydrodiol; 18, biphenyl; 19, cis-2,3-bipheyl dihydrodiol; 20, naphthalene; 21, cis-1,2-naphthalene dihydrodiol; 22, indene; 23, indan-1,2-diol; 24, 1,2-dihydronaphthalene; 25, cis-1,2-dihydroxy-1,2,3,4-tetrahydronaphthalene. The left and right panels show growth and non-growth substrates of DK17, respectively.

bioconvert a wide range of nitriles. The hydrolysis of nitrile to the corresponding carboxylic acid is catalyzed by a nitrilase or by the successive actions of a nitrile hydratase (NHase) and an amidase, which metabolizes the intermediate amide to carboxylic acid. Thus, the nitrile-converting enzymes, nitrilase and NHase, are responsible for the bioconversion of a wide variety of structurally different nitriles. The bioconversion of acrylonitrile has become attractive because of its industrial applicability in acrylamide production. Acrylamide can be prepared by the hydrolysis of acrylonitrile by NHase. This is beneficial in acrylamide production because nitrile-hydrating wholecell biocatalysts generally exhibit low or no amidase activity for acrylamide.

Because of progress in understanding microbial nitrile metabolism, NHases from Rhodococcus sp. N-774 and $R$. rhodochrous J1 have been used in the kiloton-scale production of acrylamide, which is known as one of the most commercially successful microbial biotransformations. The polyacrylamide-entrapped resting cells of $R$. rhodochrous 
PA-34 produced a total of $1,217 \mathrm{~g} / 1$ acrylamide in a partitioned fed-batch reactor recycling the entrapped cells [41]. Rhodococci with nitrilase activity was also used to convert acrylonitrile into acrylic acid, which is traditionally used for the production of diverse acrylic esters in many industries. A versatile acrylonitrile-bioconverting $R$. ruber AKSH-84 was studied for optimization of medium and biotransformation conditions for acrylic acid production [42]. R. ruber $\mathrm{TH}$, expressing NHase, amidase, and nitrilase, was transformed to a NHase-amidase double-knockout mutant, and the resultant mutant, which was still able to express nitrilase at extremely low level, was subsequently engineered to overexpress a heterologous nitrilase from $R$. rhodochrous tg1-A6 with a high activity of nitrilase. When the engineered cells expressing two nitrilases were used as a catalyst at room temperature, the amount and productivity of ammonium acrylate increased to $741.0 \mathrm{~g} / 1$ and $344.9 \mathrm{~g} / \mathrm{l} / \mathrm{h}$, respectively, which were the highest values reported to date [43].

Lignin polymer. Large amounts of small molecular aromatic compounds originate from decaying plant material containing (hemi) cellulose and lignin (a complex aromatic heteropolymer). In addition to natural lignin, large quantities of kraft lignin are formed in the pulp industry. Thus, lignin degradation products are of considerable interest as a renewable source of high-value aromatic compounds and other lignin-derived products [44]. Lignin is composed of phenylpropanoid aryl- $\mathrm{C}_{3}$ units (guaiacyl, syringyl, and $p$-hydroxyphenyl), linked together via a variety of ether and C-C bonds. The most common chemical linkage found in lignin is the $\beta$-aryl ether, accounting for $45-50 \%$ and $60 \%$ of the units in softwoods and hardwoods, respectively [45]. When these linkages are broken, a wide range of ligninderived low-molecular phenolic compounds are produced [46].

R. jostii RHA1 was intensively characterized for its degradation properties of aromatic compounds (especially, polychlorinated biphenyl and alkylbenzenes) using its catalytic enzymes and pathways. RHA1 was later shown to break down lignin and lignocellulose. In RHA1, lignin degradation is proposed to be initiated by an extracellular dye-decolorizing peroxidase $\mathrm{B}$ (DypB), resulting in vanillin as a main intermediate. Vanillin is further catabolized to vanillate and then protocatechuate by the activities of vanillin dehydrogenase $(\mathrm{Vdh})$ and vanillate $O$-demethylase (Van $A B)$, respectively, which is subjected to intradiol oxidative ring cleavage. Recombinant $\mathrm{DypB}$ was shown to recognize the $\beta$-aryl ether structure and cleave the $C_{\alpha}-C_{\beta}$ bond in $\beta$-aryl ether lignin model compounds, producing vanillin, a valuable chemical for food flavoring. DypB also showed linkage cleavage activity for kraft lignins and wheat straw lignocellulose [47]. Interestingly, when encapsulated with encapsulin protein from RHA1, the assembled complex DypB showed an 8-fold enhanced lignin degradation activity, when compared with DypB alone [48]. A $v d h$ gene deletion mutant of RHA1, when grown on minimal medium containing $2.5 \%$ wheat straw lignocellulose and $0.05 \%$ glucose, accumulated vanillin (96 mg/1 after 6 days) [10]. Natural vanillin production is of intense interest to the flavor and fragrance industry.

Terpenes and terpenoids. Terpenes, composed of isoprene units, are a large and diverse class of organic compounds produced by a variety of plants. They are used in the food, cosmetics, pharmaceutical, and biotechnology industries. Terpenoids (isoprenoids) are known as modified terpenes involving methyl groups that have been moved or removed, or added oxygen atoms, thus containing additional functional groups. Terpenes and terpenoids are the primary constituents of plant and flower essential oils, and are widely used as fragrances and flavors in the food, pharmaceutical, and cosmetic industries. Synthetic variations and derivatives of natural terpenes and terpenoids also greatly expand the variety of aromas used in perfumery and flavors used as food additives. Monoterpenes are branched-chain $C_{10}$ hydrocarbons with two isoprene units that are widely distributed in nature, with more than 400 different monoterpenes identified. Thus, bacteria with the ability to degrade monoterpenes are relatively common, and a degradation pathway via initial oxidation of the benzylic methyl group has been extensively studied at the biochemical and genetic levels. For example, in the cases of $p$-cymene and limonene, the initial oxidation of the benzylic methyl groups of monoterpenes was performed by a monooxygenase, producing corresponding alcohols that were oxidized to aldehydes and then acids by respective dehydrogenases. The further degradation of those acidic intermediates was processed through lower degradation pathways [49].

Limonene, a monocyclic monoterpene, is the main constituent of orange and lemon peel oil (92-96\%), which is a byproduct of the fruit juice industry, and is present in a mixture of both enantiomers (4R)-limonene and (4S)limonene. In plants, the terpenoid carvone is biosynthesized via ring hydroxylation of limonene to carveol, the hydroxyl group of which is subsequently oxidized to ketone, resulting in carvone. There have been many reports concerning the biotransformation by microorganisms of low-priced limonene to more valuable naturally flavored monoterpenoids such 
as carveol and carvone. Carveol and carvone are widely used in the flavor and fragrance industries. Carveol also has chemopreventive potential for mammary carcinogenesis with little or no toxicity. Oils containing carvones are used in aromatherapy and alternative medicine.

R. erythropolis DCL14, which is able to grow on limonene and limonene derivatives such as carveol and carvone, was reported to metabolize limonene via an initial attack at the 1,2 double bond by monooxygenase, leading to limonene1,2-epoxide. Limonene-1,2-epoxide is converted to limonene1,2-diol by limonene epoxide hydrolase activity [50]. DCL14 also metabolized all four stereoisomers of carveol via oxidation by carveol dehydrogenase to two carvone enantiomers [51]. In a laboratory-scale aqueous/organic system, using an air-driven column reactor, DCL14 whole cells biotransformed carveol (a mixture of isomers) to carvone ( $0.68 \mathrm{~g}$ carvone/g carveol) [52]. The chemostatgrown cells of toluene-degrading R. opacus PWD4 were able to hydroxylate (4R)-limonene (D-limonene) to enantiomerically pure trans-carveol, with a final yield of $94-97 \%$. Another toluene degrader ( $R$. globerulus PWD8) oxidized most of the formed trans-carveol to (4R)-carvone, which is used as a flavor compound [53]. As another example of the use of rhodococcal microbial or enzymatic catalysis, although the chemical-enzymatic mechanism is presently unclear, the resting cells of R.erythropolis MLT1 converted the monoterpene $\beta$-myrcene to geraniol, which has a rose-like scent and is commonly used in perfumes. A scalable process for geraniol production is being developed [54].

Cholesterol. Steroids are organic compounds composed of four fused rings (three six-member cyclohexane rings $\mathrm{A}$, $\mathrm{B}$, and $\mathrm{C}$; and one five-member cyclopentane ring $\mathrm{D}$ ). Steroids vary by the functional groups attached to this four-ring core and by the oxidation state of the rings. As an example, cholesterol, having a hydroxyl group attached at position C-3 in ring A, is an important component of cell membranes and is biosynthesized by all animal cells and even by plants in very small amounts. Cholesterol is a major starting material for the production of steroid drugs and hormones, because of the low cost and ease of transformation [9]. Microorganisms capable of degrading cholesterol as a common carbon source have been used to promote selective removal of steroid side chains, while leaving the steroid rings intact [55].

Degradation of the cholesterol rings is initiated by either an $\mathrm{NAD}^{+}$-dependent $3 \beta$-hydroxysteroid dehydrogenase or cholesterol oxidase, depending on the strain [56]. The side chain degradation is initiated by a cytochrome P450 that catalyzes the oxidation of $\mathrm{C} 26$ to the corresponding carboxylic acid, and side chain removal proceeds via a mechanism similar to the $\beta$-oxidation of fatty acids. However, it is not clear whether the side chain and ring degradation processes occur simultaneously or independently [9]. In the case of R. jostii RHA1, the reaction product of the side chain removal and initial ring oxidation (4-androstene3,17-dione) is metabolized to 1,4-androstadiene-3,17-dione, which is later subjected to successive $B$ and A ring cleavages by a nonenzymatic reaction and an extradiol dioxygenase (HsaC enzyme), respectively [57]. All the rhodococci genes presently sequenced are predicted to encode this pathway, suggesting that cholesterol degradation is a common characteristic of this genus [9]. Bioconversion of steroids has been applied to resting cells in aqueous/organic solvents in two-phase systems [58]. Because the oxidation of cholesterol to cholestenone (cholest-4-en-3-one) by cholesterol oxidase is the first step of ring oxidation in microbial degradation, cholestenone production by cholesterol oxidase-producing rhodococci cells was investigated as a model system for the bioconversion of steroids. A systematic investigation for efficient biotransformation of cholesterol to cholestenone was performed with cell-linked and extracellular cholesterol oxidases from R. erythropolis ATCC 25544 [59].

\section{Concluding Remarks}

Over the past decade, bioinformatics has been integrated with biodegradation and biocatalysis to produce new research tools useful in databases [60-62]. With online databases linking genomic information, such as UM-BBD (http://umbbd.msi.umn.edu/) and KEGG (http://www. genome.ad.jp/kegg/), the functions of genes within these genomic sequences can be assigned, and biocatalytic reactions and biodegradation pathways can be predicted $[63,64]$. These pathway prediction systems allow prediction of the degradation pathways and identification of the enzymes involved in the degradation pathways.

As of mid-May 2017, a total of 226 rhodococci genome sequences have been submitted to the National Center for Biotechnology Information (USA). These sequences can be used for genome-scale comparisons of the genetic relatedness among rhodococcal strains and metabolic characteristics involving pathways, reactions, catalytic enzymes, and metabolites. Genomic analyses of Rhodococcus strains have already provided insights into their biotechnological potentials and ecological roles [65, 66]. As stated by Arora and Bae [67], bioinformatics and biodegradation are two critical scientific fields in applied microbiology and 


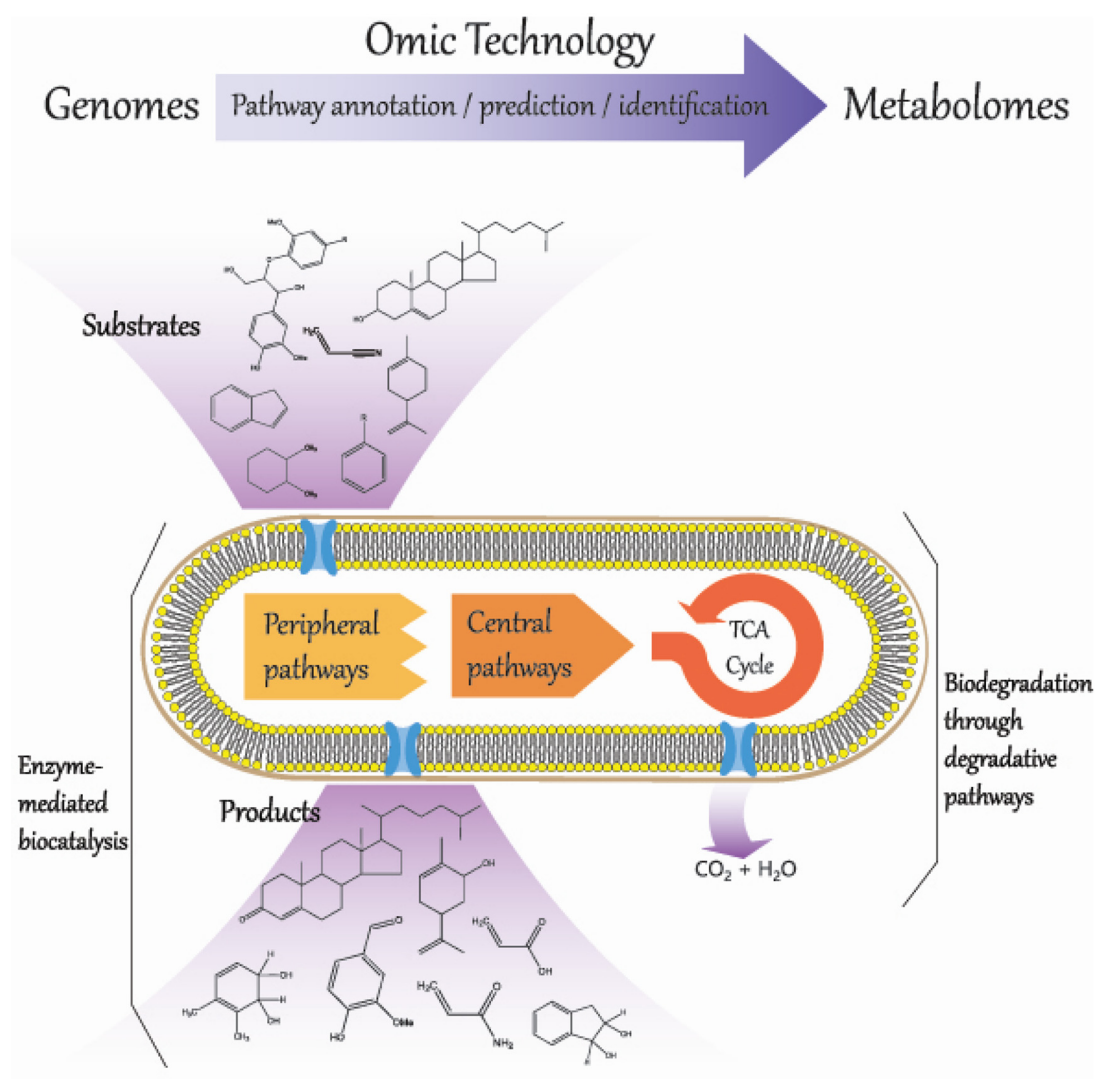

Fig. 5. Schematic illustration of Rhodococcus biodegradative pathways and omics technology outline.

biotechnology. In this context, the cutting-edge "omics" technology, combined with genetic engineering tools, can exploit extensively the potential of biodegradative rhodococci to develop new approaches for biodegradation and biocatalysis. The concept of "from genomics to metabolomics" has already been successfully applied to biodegradation and biocatalysis [68, 69]. This approach would also be very useful for developing strategies to harness the real and potential value of biodegradative rhodococci (Fig. 5).

The catabolic enzymes specifically adapted to low temperatures (cold-active enzymes) are thought to be a product from cold adaptation mechanisms used by microorganisms. The cold-active enzymes from coldadapted microbes show high catalytic activities at low temperatures, which makes them excellent biocatalysts in biotechnological and industrial applications. However, few reports have been published about rhodococcal cold-active enzymes, in spite of their biotechnological potential [70, 71]. Thus, the isolation and characterization of novel coldactive enzymes, such as esterase, protease, lipase, cellulase, and peroxidase, from rhodococci inhabiting different cold environments (polar marine, soil, and glacier) should be an important research subject in the near future.

\section{Acknowledgments}

This work was partially supported by "Modeling responses of terrestrial organisms to environmental changes on King George Island" (Grant No. PE18090), funded by the Korea Polar Research Institute. We thank Yoo-Min An for the illustration.

\section{Conflict of interest}

The authors have no financial conflicts of interest to declare.

\section{References}

1. Larkin MJ, Kulakov LA, Allen CC. 2006. Biodegradation by members of the genus Rhodococcus: biochemistry, physiology, and genetic adaptation. Adv. Appl. Microbiol. 59: 1-29.

2. Hwang CY, Lee I, Cho Y, Lee YM, Baek K, Jung YJ, et al. 
2015. Rhodococcus aerolatus sp. nov., isolated from subarctic rainwater. Int. J. Syst. Evol. Microbiol. 65: 465-471.

3. Goordial J, Raymond-Bouchard I, Zolotarov Y, de Bethencourt L, Ronholm J, Shapiro N, et al. 2016. Cold adaptive traits revealed by comparative genomic analysis of the eurypsychrophile Rhodococcus sp. JG3 isolated from high elevation McMurdo Dry Valley permafrost, Antarctica. FEMS Microbiol. Ecol. 92: fiv154.

4. Sinha RK, Krishnan KP, Hatha AA, Rahiman M, Thresyamma DD, Kerkar S. 2017. Diversity of retrievable heterotrophic bacteria in Kongsfjorden, an Arctic fjord. Braz. J. Microbiol. 48: 51-61.

5. Martínková L, Uhnáková B, Pátek M, Nesvera J, Kren V. 2009. Biodegradation potential of the genus Rhodococcus. Environ. Int. 35: 162-177.

6. Larkin MJ, Kulakov LA, Allen CC. 2005. Biodegradation and Rhodococcus - masters of catabolic versatility. Curr. Opin. Biotechnol. 16: 282-290.

7. Singh R, Sharma R, Tewari N, Geetanjali, Rawat DS. 2006. Nitrilase and its application as a 'green' catalyst. Chem. Biodivers. 3: 1279-1287.

8. Kim D, Yoo M, Choi KY, Kang BS, Kim TK, Hong SG, et al. 2011. Differential degradation of bicyclics with aromatic and alicyclic rings by Rhodococcus sp. strain DK17. Appl. Environ. Microbiol. 77: 8280-8287.

9. Yam KC, Okamoto S, Roberts JN, Eltis LD. 2011. Adventures in Rhodococcus - from steroids to explosives. Can. J. Microbiol. 57: 155-168.

10. Sainsbury PD, Hardiman EM, Ahmad M, Otani H, Seghezzi N, Eltis LD, et al. 2013. Breaking down lignin to high-value chemicals: the conversion of lignocellulose to vanillin in a gene deletion mutant of Rhodococcus jostii RHA1. ACS Chem. Biol. 8: 2151-2156.

11. Warren R, Hsiao WW, Kudo H, Myhre M, Dosanjh M, Petrescu A, et al. 2004. Functional characterization of a catabolic plasmid from polychlorinated-biphenyl-degrading Rhodococcus sp. strain RHA1. J. Bacteriol. 186: 7783-7795.

12. Dabrock B, Kesseler M, Averhoff B, Gottschalk G. 1994. Identification and characterization of a transmissible linear plasmid from Rhodococcus erythropolis BD2 that encodes isopropylbenzene and trichloroethene catabolism. Appl. Environ. Microbiol. 60: 853-860.

13. Patrauchan MA, Florizone C, Dosanjh M, Mohn WW, Davies J, Eltis LD. 2005. Catabolism of benzoate and phthalate in Rhodococcus sp. strain RHA1: redundancies and convergence. J. Bacteriol. 187: 4050-4063.

14. McLeod MP, Warren RL, Hsiao WW, Araki N, Myhre M, Fernandes C, et al. 2006. The complete genome of Rhodococcus sp. RHA1 provides insights into a catabolic powerhouse. Proc. Natl. Acad. Sci. USA 103: 15582-15587.

15. Choi KY, Kim D, Chae JC, Zylstra GJ, Kim E. 2007. Requirement of duplicated operons for maximal metabolism of phthalate by Rhodococcus sp. strain DK17. Biochem. Biophys.
Res. Commun. 357: 766-771.

16. Choi KY, Zylstra GJ, Kim E. 2007. Benzoate catabolite repression of the phthalate degradation pathway in Rhodococcus sp. strain DK17. Appl. Environ. Microbiol. 73: 1370-1374.

17. Yoo M, Kim D, Choi KY, Chae JC, Zylstra GJ, Kim E. 2012. Draft genome sequence and comparative analysis of the superb aromatic-hydrocarbon degrader Rhodococcus sp. strain DK17. J. Bacteriol. 194: 4440.

18. de Carvalho CC, Costa SS, Fernandes P, Couto I, Viveiros M. 2014. Membrane transport systems and the biodegradation potential and pathogenicity of genus Rhodococcus. Front Physiol. 5: 133.

19. Maruyama T, Ishikura M, Taki H, Shindo K, Kasai H, Haga M, et al. 2005. Isolation and characterization of $o$-xylene oxygenase genes from Rhodococcus opacus TKN14. Appl. Environ. Microbiol. 71: 7705-7715.

20. Kim D, Chae JC, Zylstra GJ, Kim YS, Kim SK, Nam MH, et al. 2004. Identification of a novel dioxygenase involved in metabolism of $o$-xylene, toluene, and ethylbenzene by Rhodococcus sp. strain DK17. Appl. Environ. Microbiol. 70: 7086-7092.

21. Kim D, Chae JC, Zylstra GJ, Sohn HY, Kwon GS, Kim E. 2005. Identification of two-component regulatory genes involved in $o$-xylene degradation by Rhodococcus sp. strain DK17. J. Microbiol. 43: 49-53.

22. Kohyama E, Yoshimura A, Aoshima D, Yoshida T, Kawamoto H, Nagasawa T. 2006. Convenient treatment of acetonitrile-containing wastes using the tandem combination of nitrile hydratase and amidase-producing microorganisms. Appl. Microbiol. Biotechnol. 72: 600-606.

23. Paisio CE, Quevedo MR, Talano MA, González PS, Agostini E. 2014. Application of two bacterial strains for wastewater bioremediation and assessment of phenolics biodegradation. Environ. Technol. 35: 1802-1810.

24. Jeong E, Hirai M, Shoda M. 2008. Removal of $o$-xylene using biofilter inoculated with Rhodococcus sp. BTO62. J. Hazard. Mater. 152: 140-147.

25. Jeong E, Hirai M, Shoda M. 2009. Removal of xylene by a mixed culture of Pseudomonas sp. NBM21 and Rhodococcus sp. BTO62 in biofilter. J. Biosci. Bioeng. 108: 136-141.

26. Rodrigues JL, Kachel CA, Aiello MR, Quensen JF, Maltseva OV, Tsoi TV, et al. 2006. Degradation of aroclor 1242 dechlorination products in sediments by Burkholderia xenovorans LB400 (ohb) and Rhodococcus sp. strain RHA1 $(f c b)$. Appl. Environ. Microbiol. 72: 2476-2482.

27. Baxter J, Garton NJ, Cummings SP. 2006. The impact of acrylonitrile and bioaugmentation on the biodegradation activity and bacterial community structure of topsoil. Folia Microbiol. 51: 591-597.

28. Kim D, Park MJ, Koh SC, So JS, Kim E. 2002. Three separate pathways for the initial oxidation of limonene, biphenyl, and phenol by Rhodococcus sp. strain T104. J. Microbiol. 40: 86-89. 
29. Suttinun O, Müller R, Luepromchai E. 2009. Trichloroethylene cometabolic degradation by Rhodococcus sp. L4 induced with plant essential oils. Biodegradation 20: 281-291.

30. Suttinun O, Müller R, Luepromchai E. 2010. Cometabolic degradation of trichloroethene by Rhodococcus sp. strain L4 immobilized on plant materials rich in essential oils. Appl. Environ. Microbiol. 76: 4684-4690.

31. Labbé D, Margesin R, Schinner F, Whyte LG, Greer CW. 2007. Comparative phylogenetic analysis of microbial communities in pristine and hydrocarbon-contaminated Alpine soils. FEMS Microbiol. Ecol. 59: 466-475.

32. Margesin R. 2007. Alpine microorganisms: useful tools for low-temperature bioremediation. J. Microbiol. 45: 281-285.

33. Kim D, Yoo M, Kim E, Hong SG. 2015. Anthranilate degradation by a cold-adapted Pseudomonas sp. J. Basic Microbiol. 55: 354-362.

34. Margesin R, Moertelmaier C, Mair J. 2013. Low-temperature biodegradation of petroleum hydrocarbons ( $n$-alkanes, phenol, anthracene, pyrene) by four actinobacterial strains. Int. Biodeterior. Biodegradation 84: 185-191.

35. Lee GLY, Ahmad SA, Yasid NA, Zulkharnain A, Convey P, Johari WLW, et al. 2018. Biodegradation of phenol by coldadapted bacteria from Antarctic soils. Polar Biol. 41: 553-562.

36. de Carvalho CC, da Fonseca MM. 2005. The remarkable Rhodococcus erythropolis. Appl. Microbiol. Biotechnol. 67: 715-726.

37. Nolan LC, O'Connor KE. 2008. Dioxygenase- and monooxygenase-catalysed synthesis of cis-dihydrodiols, catechols, epoxides and other oxygenated products. Biotechnol. Lett. 30: 1879-1891.

38. Kim D, Yoo M, Choi KY, Kang BS, Kim E. 2013. Characterization and engineering of an $o$-xylene dioxygenase for biocatalytic applications. Bioresour. Technol. 145: 123-127.

39. Priefert H, O'Brien XM, Lessard PA, Dexter AF, Choi EE, Tomic $S$, et al. 2004. Indene bioconversion by a toluene inducible dioxygenase of Rhodococcus sp. I24. Appl. Microbiol. Biotechnol. 65: 168-176.

40. Pandi-Perumal SR, Srinivasan V, Poeggeler B, Hardeland R, Cardinali DP. 2007. Drug insight: the use of melatonergic agonists for the treatment of insomnia - focus on ramelteon. Nat. Clin. Pract. Neurol. 3: 221-228.

41. Raj J, Prasad S, Sharma NN, Bhalla TC. 2010. Bioconversion of acrylonitrile to acrylamide using polyacrylamide entrapped cells of Rhodococcus rhodochrous PA-34. Folia Microbiol. 55: 442-446.

42. Kamal A, Kumar MS, Kumar CG, Shaik T. 2011. Bioconversion of acrylonitrile to acrylic acid by Rhodococcus ruber strain AKSH-84. J. Microbiol. Biotechnol. 21: 37-42.

43. Sun J, Yu H, Chen J, Luo H, Shen Z. 2016. Ammonium acrylate biomanufacturing by an engineered Rhodococcus ruber with nitrilase overexpression and double-knockout of nitrile hydratase and amidase. J. Ind. Microbiol. Biotechnol. 43: 1631-1639.

44. Zakzeski J, Bruijnincx PC, Jongerius AL, Weckhuysen BM.
2010. The catalytic valorization of lignin for the production of renewable chemicals. Chem. Rev. 110: 3552-3599.

45. Bugg TDH, Ahmad M, Hardiman EM, Rahmanpour R. 2011. Pathways for degradation of lignin in bacteria and fungi. Nat. Prod. Rep. 28: 1883-1896.

46. Gellerstedt G. 2015. Softwood kraft lignin: raw material for the future. Ind. Crops Prod. 77: 845-854.

47. Ahmad M, Roberts JN, Hardiman EM, Singh R, Eltis LD, Bugg TD. 2011. Identification of DypB from Rhodococcus jostil RHA1 as a lignin peroxidase. Biochemistry 50: 5096-5107.

48. Rahmanpour R, Bugg TD. 2013. Assembly in vitro of Rhodococcus jostii RHA1 encapsulin and peroxidase DypB to form a nanocompartment. FEBS J. 280: 2097-2104.

49. Bae HW, Kim D, Choi KY, Kwon NR, Chae JC, Zylstra GJ, et al. 2007. Functional identification of $p$-cumate operons in the terpene-degrading Rhodococcus sp. strain T104. FEMS Microbiol. Lett. 266: 54-59.

50. De Carvalho CCCR, Van Keulen F, Da Fonseca MMR. 2000. Biotransformation of limonene-1,2-epoxide to limonene-1,2diol by Rhodococcus erythropolis cells: an introductory approach to selective hydrolysis and product separation. Food Technol. Biotechnol. 38: 181-185.

51. van der Werf MJ, Boot AM. 2000. Metabolism of carveol and dihydrocarveol in Rhodococcus erythropolis DCL14. Microbiology 146: 1129-1141.

52. de Carvalho CC, Poretti A, da Fonseca MM. 2005. Cell adaptation to solvent, substrate and product: a successful strategy to overcome product inhibition in a bioconversion system. Appl. Microbiol. Biotechnol. 69: 268-275.

53. Duetz WA, Fjällman AH, Ren S, Jourdat C, Witholt B. 2001. Biotransformation of D-limonene to $(+)$ trans-carveol by toluene-grown Rhodococcus opacus PWD4 cells. Appl. Environ. Microbiol. 67: 2829-2832.

54. Thompson ML, Marriott R, Dowle A, Grogan G. 2010. Biotransformation of $\beta$-myrcene to geraniol by a strain of Rhodococcus erythropolis isolated by selective enrichment from hop plants. Appl. Microbiol. Biotechnol. 85: 721-730.

55. García JL, Uhía I, Galán B. 2012. Catabolism and biotechnological applications of cholesterol degrading bacteria. Microb. Biotechnol. 5: 679-699.

56. Yang X, Dubnau E, Smith I, Sampson NS. 2007. Rv1106c

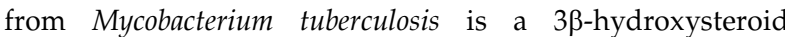
dehydrogenase. Biochemistry 46: 9058-9067.

57. Van der Geize R, Yam K, Heuser T, Wilbrink MH, Hara H, Anderton MC, et al. 2007. A gene cluster encoding cholesterol catabolism in a soil actinomycete provides insight into Mycobacterium tuberculosis survival in macrophages. Proc Natl. Acad. Sci. USA 104: 1947-1952.

58. Fernandes P, Cruz A, Angelova B, Pinheiro HM, Cabral JMS. 2003. Microbial conversion of steroid compounds: recent developments. Enzyme Microb. Technol. 32: 688-705.

59. Sojo MM, Bru RR, García-Carmona FF. 2002. Rhodococcus erythropolis ATCC 25544 as a suitable source of cholesterol oxidase: cell- 
linked and extracellular enzyme synthesis, purification and concentration. BMC Biotechnol. 2: 3.

60. Arora PK, Kumar M, Chauhan A, Raghava GP, Jain RK. 2009. OxDBase: a database of oxygenases involved in biodegradation. BMC Res. Notes 2: 67.

61. Carbajosa G, Trigo A, Valencia A, Cases I. 2009. Bionemo: molecular information on biodegradation metabolism. Nucleic Acids Res. 37 (Database issue): D598-D602.

62. Caspi R, Altman T, Dreher K, Fulcher CA, Subhraveti P, Keseler IM, et al. 2012. The MetaCyc database of metabolic pathways and enzymes and the BioCyc collection of pathway/ genome databases. Nucleic Acids Res. 40(D1): D742-D753.

63. Ellis LB, Wackett LP. 2012. Use of the University of Minnesota Biocatalysis/biodegradation Database for study of microbial degradation. Microb. Inform. Exp. 2: 1.

64. Kanehisa M. 2013. Chemical and genomic evolution of enzyme-catalyzed reaction networks. FEBS Lett. 587: 2731-2737.

65. Fernández de Las Heras L, Perera J, Navarro Llorens JM. 2014. Cholesterol to cholestenone oxidation by ChoG, the main extracellular cholesterol oxidase of Rhodococcus ruber strain Chol-4. J. Steroid Biochem. Mol. Biol. 139: 33-44.

66. Khairy H, Meinert C, Wübbeler JH, Poehlein A, Daniel R, Voigt B, et al. 2016. Genome and proteome analysis of Rhodococcus erythropolis MI2: elucidation of the 4,4'dithiodibutyric acid catabolism. PLoS One 11: e0167539.

67. Arora PK, Bae H. 2014. Integration of bioinformatics to biodegradation. Biol. Proced. Online 16: 8.

68. Pérez-Pantoja D, De la Iglesia R, Pieper DH, González B. 2008. Metabolic reconstruction of aromatic compounds degradation from the genome of the amazing pollutantdegrading bacterium Cupriavidus necator JMP134. FEMS Microbiol. Rev. 32: 736-794.

69. Romero-Silva MJ, Méndez V, Agulló L, Seeger M. 2013. Genomic and functional analyses of the gentisate and protocatechuate ring-cleavage pathways and related 3-hydroxybenzoate and 4-hydroxybenzoate peripheral pathways in Burkholderia xenovorans LB400. PLoS One 8: e56038.

70. De Santi C, Tedesco P, Ambrosino L, Altermark B, Willassen NP, de Pascale D. 2014. A new alkaliphilic coldactive esterase from the psychrophilic marine bacterium Rhodococcus sp.: functional and structural studies and biotechnological potential. Appl. Biochem. Biotechnol. 172: 3054-3068.

71. Santiago M, Ramírez-Sarmiento CA, Zamora RA, Parra LP. 2016. Discovery, molecular mechanisms, and industrial applications of cold-active enzymes. Front. Microbiol. 7: 1408.

72. Nagasawa T, Mathew CD, Mauger J, Yamada H. 1988. Nitrile hydratase-catalyzed production of nicotinamide from 3-cyanopyridine in Rhodococcus rhodochrous J1. Appl. Environ. Microbiol. 54: 1766-1769.

73. Gorlatov SN, Maltseva OV, Shevchenko VI, Golovleva LA. 1989. Degradation of chlorophenols by a culture of
Rhodococcus erythropolis. Mikrobiologiya 58: 802-806. [Microbiology 58: 647-651]

74. Bhalla TC, Miura A, Wakamoto A, Ohba Y, Furuhashi K. 1992. Asymmetric hydrolysis of $\alpha$-aminonitriles to optically active amino acids by a nitrilase of Rhodococcus rhodochrous PA-34. Appl. Microbiol. Biotechnol. 37: 184-190.

75. Chung SY, Maeda M, Song E, Horikoshi K, Kudo T. 1994. Isolation and characterization of a gram-positive polychlorinated biphenyl-degrading bacterium, Rhodococcus erythropolis strain TA421, from a termite ecosystem. Biosci. Biotechnol. Biochem. 58: 2111-2113.

76. Blakey AJ, Colby J, Williams E, O'Reilly C. 1995. Regio- and stereo-specific nitrile hydrolysis by the nitrile hydratase from Rhodococcus AJ270. FEMS Microbiol. Lett. 129: 57-62.

77. Masai E, Yamada A, Healy JM, Hatta T, Kimbara K, Fukuda M, et al. 1995. Characterization of biphenyl catabolic genes of gram-positive polychlorinated biphenyl degrader Rhodococcus sp. strain RHA1. Appl. Environ. Microbiol. 61: 2079-2085.

78. Hernandez BS, Koh SC, Chial M, Focht DD. 1997. Terpeneutilizing isolates and their relevance to enhanced biotransformation of polychlorinated biphenyls in soil. Biodegradation 8: 153-158.

79. Chartrain M, Jackey B, Taylor C, Sandford V, Gbewonyo K, Lister $\mathrm{L}$, et al. 1998. Bioconversion of indene to cis $(1 S, 2 R)$ indandiol and trans $(1 R, 2 R)$ indandiol by Rhodococcus species. J. Ferment. Bioeng. 86: 550-558.

80. Yakimov MM, Giuliano L, Bruni V, Scarfì S, Golyshin PN. 1999. Characterization of Antarctic hydrocarbon-degrading bacteria capable of producing bioemulsifiers. New Microbiol. 22: 249-256.

81. Kim D, Kim YS, Kim SK, Kim SW, Zylstra GJ, Kim YM, et al. 2002. Monocyclic aromatic hydrocarbon degradation by Rhodococcus sp. strain DK17. Appl. Environ. Microbiol. 68: 3270-3278.

82. Margesin R, Fonteyne PA, Redl B. 2005. Low-temperature biodegradation of high amounts of phenol by Rhodococcus spp. and basidiomycetous yeasts. Res. Microbiol. 156: 68-75.

83. Na KS, Kuroda A, Takiguchi N, Ikeda T, Ohtake H, Kato J. 2005. Isolation and characterization of benzene-tolerant Rhodococcus opacus strains. J. Biosci. Bioeng. 99: 378-382.

84. Sekine M, Tanikawa S, Omata S, Saito M, Fujisawa T, Tsukatani N, et al. 2006. Sequence analysis of three plasmids harboured in Rhodococcus erythropolis strain PR4. Environ. Microbiol. 8: 334-346.

85. Ma Y, Yu H, Pan W, Liu C, Zhang S, Shen Z. 2010. Identification of nitrile hydratase-producing Rhodococcus ruber $\mathrm{TH}$ and characterization of an amiE-negative mutant. Bioresour. Technol. 101: 285-291.

86. Cai Q, Zhang B, Chen B, Zhu Z, Lin W, Cao T. 2014. Screening of biosurfactant producers from petroleum hydrocarbon contaminated sources in cold marine environments. Mar. Pollut. Bull. 86: 402-410. 